\title{
A relação linguagem, pensamento e ação na microgênese das funções psíquicas superiores
}

\author{
JairoWerner ${ }^{\star}$ \\ Federal Fluminense University, Niterói, RJ, Brazil
}

Resumo

O objetivo deste artigo é demonstrar, de forma concreta, a mediação da fala na constituição das funções psíquicas superiores do sujeito, buscando articular autores da vertente histórico-cultural, como Vigotski, com a perspectiva metodológica de Heloisa Marinho, pesquisadora brasileira que centrou na linguagem sua contribuição pioneira no âmbito do desenvolvimento infantil. A metodologia utilizada fundamentou-se no estudo da relação oral-gráfica (MARINHO; WERNER,1982), e mamostra constituída por três mil crianças, foi realizada a análise microgenética-indiciária (WERNER,1999,2001) da atividade gráfica de menino de dois anos de idade cronológica, oriundo da creche UFF. Como resultado, foi possível ilustrar como, na vigência de processo de interaçãointerlocução adulto-criança e criança-crianças, ocorrem transformações qualitativas nas funções psíquicas (microgênese), nas quais a mediação, por meio dos signos da linguagem (mediação semiótica), reveste-se de papel fundante e constitutivo.

Palavras-chave: microgênese; desenvolvimento da linguagem; mediação semiótica; funções psíquicas superiores; Vigotski.

\section{The relationship between language, thought, and action in the microgenesis of higher mental functions}

\begin{abstract}
Objective: to concretely illustrate the role of language mediation in the constitution of the subject's higher mental functions, seeking to articulate authors of a cultural-historical background, such as Vygotsky, along with the methodological perspective of Heloisa Marinho, a Brazilian researcher who focused on language and was a pioneering contributor to the area of child development. Methodology: based on the study of the relationship between the oral and graphic mode of communication (MARINHO; WERNER,1982) and using Werner's (2012) observation script, a microgenetic analysis of graphic activity (WERNER,1999,2001) was conducted with a sample of 3000 children on a two-year-old boy from the university nursery. Result: it was possible to illustrate the way in which, in the setting of adult-child and child-child interactions, qualitative transformations occur in psychological functions in which semiotic mediation has a foundational and constitutional role.
\end{abstract}

Keywords: microgenesis; language development; semiotic mediation; higher mental functions; Vygotsky.

\section{Introduction}

The importance of language in the constitution of the subject

Due to the predominance of the auditory sense, interior language is nearly always expressed as such: we think by speaking. Although most of the time words that are thought are not externalized through sound, muscular innervation puts them on the verge of expression. When, while making an effort to remember something, this innervation becomes more intense, we unintentionally think aloud, that is, spoken soliloquy replaces prior thought. Through language symbols, the individual stimulates himself/herself and makes past experience easily accessible for the delineation and planning of future behavior. Thus, as a rehearsal of exterior activity that is both fast and easy, language facilitates mental experience. For example, in forming a mental plan to travel from one location to another, we evoke our past experience through symbols to regulate future behavior. Interior language, which reminds us of the various available means of transportation, allows us to choose the preferred option beforehand, thus saving future indecision. Past experiences are useful for future behavior due to the ability to relive the past through language. According to Dewey, named objects and events are freed

\footnotetext{
^Coordinator of the Psychopathology and Child Psychiatry Research Group Child and Adolescent Mental Health in the Cultural-Historical Perspective of the College of Medicine, Federal Fluminense University. Address fo correspondence: Universidade Federal Fluminense, Faculdade de Medicina. Ministro Octávio Kelly, 453 - Icarai. CEP: 24220-300 - Niteroi, RJ - Brazil E-mail: jairowerner@globo.com
}

from local and incidental contingencies if, independently of a particular place or time, they are brought to the focus of attention by language symbols (Marinho, 1935, p.4).

In 1935, Heloisa Marinho, after finishing her degree in philosophy and psychology at the University of Chicago, one of the most progressive universities of her time, published the unprecedented article "Da linguagem na formação do $\mathrm{Eu}$ [Of language in the formation of the self]," from which the above quotation is taken. Thus, we seek to emphasize the theme that this paper will address: the role of language in the constitution of higher mental functions of the subject.

With this objective, this research seeks to give expression to different authors from the perspective of cultural-historical psychology. It primarily encompasses the tradition of Vygostky, along with the research and methodological perspective of Heloisa Marinho, a Brazilian researcher who focused her pioneering contribution to the area of early childhood education and the study of children's language (Marinho,1955).

The relationship between language, thought, and action

The theoretical framework developed by Werner (1997, p. 12-20) concerning the relationship between language, thought, and action may be useful for this research as it sheds light on the microgenesis of the higher mental functions, as indicated below. 
The constitution of the subject is not a linear mechanical process that comprises the action of the environment upon a passive individual. Rather, it stems from the isolated action of an active individual on his or her environment involving a "reciprocal formative process of cultural immersion and the simultaneous emergence of the singular individuality in the context of social practice" (Smolka, Góes \& Pino, 1995, p. 179).

The participation of the other in the constitution of the subject is significant in as much as the relationship of the subject to the world is only possible through another subject's mediation: "the path that goes from the object to the child and then again back to the object passes through another person" (Vygotsky, 1988, p.33).

One of the consequences of this mediation is the relationship between thought and language. Vygotsky underscores how the appropriation of language - a system of culturally organized linguistic signs - involves a radical change in the constitution of thought and consciousness. Typical human thought is constituted by language, for it is from the moment language developmentally comes into play that thought becomes verbal and speech rational. However, the emergence of verbal thought does not occur mechanically. Language internalization and the development of verbal thought occurs over a prolonged process of change, which, in turn, alters the way the subject operates in reality.

Concerning the singular character of the understanding and synthesis of the constituent events of communication and thought, Vygostky (1987, p.5) stated the following: "real human communication presupposes a generalized attitude, which constitutes an advanced stage of development of the meaning of words."

Conceptualization depends as much on the meaning of words as on the meaning that they assume in a given context. For this reason, subjects in interaction might not imply the same thing even if the communicated words are familiar to them both.

The sense of a word is the sum of all the psychological events that the word calls forth in our consciousness. Meaning is only one of the zones of sense: it is the most stable and precise one. A word acquires its sense in the context of what arises and in different contexts its sense is thus altered [...]. In interior speech [...] a single word is so saturated with sense that it would take many words to explain it with exterior speech (Vygotsky, 1987, p.125-126).

In addressing the role of language, Vygostky makes reference to various functions throughout his work. As Wertsch (1988) comments, his discussions indicate a categorization of opposite pairs (for example: signalizing/ meaningful; communicative/intellectual; social/individual; indicative/symbolic). Although all of these elaborations are indispensable to gain an understanding of the semiotic view of the psyche, it may be more productive, given the diversity of identified functions, to consider them as inseparable levels of the same semiotic and dia- logic process. Nevertheless, it is worth highlighting the interpretations of the regulatory language function, which permits actions to be organized and planned.

Before controlling his or her own behavior, the child starts to control the environment with the help of speech. This produces relationships with the environment in addition to a new organization of his or her own behavior (Vygotsky, 1988, p.27).

The "regulatory language function" (RLF) is also related to Vygotsky's concept of semiotic mediation and is a construct that provides elements to support theoretical and methodological issues.

In addition to its communicative and constitutive functions as already mentioned, language has other important functions, such as planning and organizing actions and self-regulating the subject.

With regard to the planning and organizing of actions and typical human thoughts, it can be observed in Vygostky's various works that he considers the moment in which a practical action and speech-until then considered independent lines - converge, to be "the [...] most meaningful thing in the course of intellectual development, which gives rise to specifically human forms of practical and abstract intelligence" (Vygostsky, 1987, p.24).

Further along these lines, the genesis of the planning language function is observed in the child's use of signs: at the beginning of his/her development, the child uses different forms of language for affective communication: crying, babbling, first words, short phrases, gestures, etc. These basic forms of communication are oriented toward other individuals and receive meaning from their understanding. Simultaneously, the child explores objects that are in his or her visual field (raising his/her hand, picking up objects, placing them in his/her mouth, ringing a bell and looking for the origin of the sound, putting together and taking apart cubes of different sizes, scribbling, etc.) without the need to speak. Gradually, nonetheless, speech begins to accompany action (for example, to complement it); following this, speech assumes an active role in the planning and organization of action ("I am going to draw a house," or "I am painting red here") and in devising solution for a problem ("I am going to climb on the table to get the candy").

[Language initially] follows action, being produced and overpowered by the activity. Later, however, when speech moves to the start of the activity, a new relationship arises between word and action. At that moment speech takes control, determines, and dominates the course of action; the planning function of speech arises, in addition to the already existing language function of reflecting the exterior world (Vygotsky, 1988, p. 29, emphasis added).

Along with the planning and organizing language function, the child begins to master the potential to regulate, with the use of speech, the observable activity of manipulating objects to solve problems. Here is the genesis of the regulation of his/her own behavior: "[...] speech, in addition to facilitating the child's effective manipulation of 
objects, also controls the child's own behavior. [...] [they] acquire the ability to be both subject and object of their own behavior" (Vygotsky, 1988, p.29, emphasis added).

In order to highlight the transition from the communicative language function to that of self-regulation, Vygotsky appropriates and transforms the Piagetian concept of "egocentric speech." In contrast to Piaget, who puts egocentric language between the individual and social language, Vygostky considers it to be a form of transition from social (communicative) language to individual language (in the sense of self-regulation). Thus, at the same time as the form of speech is directed at the other (interpersonal), it is also simultaneously directed at oneself (intrapersonal).

[...] egocentric speech is an evolutionary stage from external language $[\ldots]$, social, dialogical, to internal language [...], which would preserve from the former certain linguistic properties. The presence of egocentric speech reflects the emergence of a new self-regulatory, reflexive language function [...] (Morato, 1996, p.98).

"Exterior speech" (the communicatory function) addresses the interaction between the individual and other people, whereas "interior speech" (the intellectual language function) assumes the role of structuring thought. Given the fact that these functions are necessarily intertwined, a relationship between thoughts and words can only be explained, in all of its complexity, through a comprehension of the psychological nature of "interior speech."

Upon the internalization of the speech of the other, the child acquires self-regulatory modes and begins orienting himself/herself to a new conscious-volitional plan: "The level of conscious-volitional regulation is characterized by the active participation of the subject in the direction and execution of his/her behavior through consciously established aims" (Rey, 1987, p.6).

Another aspect to be considered in this process is that the basic unit of the signs that are present in speech is in their cognitive-affective "meaning." Therefore, the RLF is dependent on the presence of a certain degree of affectivity in the dynamic dialogue for its emergence.

Although Vygostky has particularly focused on the meaning-making process and verbal interactions, his analyses do not arrive at an explicit consideration of the dynamics of the dialogic process. However, to expand the semiotic theses introduced by him, some contemporary authors have sought to link them to M. Bakhtin's propositions on the dialogic.

It is in the center of the dialogic movement that individuals become subjects, configured by the other, by words (Smolka, Góes \& Pino, 1995, p.181).

Bakhtin's reflections contribute to the understanding of the radical role of the other in the enunciation of the subject's mental activity. "It is not the subject's mental activity that organizes [his/her] expression, but, to the contrary, it is the expression that organizes the mental activity, that models and determines its orientation" (Bakhtin, 1988, p. 112, emphasis added).
In the dialogic relationship, in addition to the interlocutor, the immediate social conditions and the ideological horizon-(de)limited by social and temporal boundaries - determine the actual conditions of the subject's expression and organize his or her mental activity.

Also considering that in this perspective, a qualitative distinction between content (interior) and expression (exterior) does not exist, and that both have the same semiotic nature, the importance of the other and the collective in the formation of individual consciousness becomes evident.

For Bakhtin (1988, p. 113), the word-as a symbol and not the mere embodiment of sound-is oriented toward the other and by the other: "every word serves one in relation to another. Through words, I define myself in relation to the other, that is, ultimately, the collective."

Thus, the more organized and meaningful the collective to whom the subject is oriented is, and the more he/she is oriented to this collective and to the other, the more complex his/her interior world will be, and the more organized and strong his/her consciousness and mental activity will bewhat Bakhtin calls the "mental activity of the we."

On another pole, we find the "mental activity of the self," that is, the more "inward looking" the individual, the more he/she loses the sense of otherness (I-you), and consequently, loses clarity and consciousness about him/ herself - regressing, and thus, approaching the physiological reaction of an animal.

As for the meaning of words, Bhaktin believes that verbal elements (words, sound, etc.) and non-verbal elements (context, intonation, etc.) participate in enunciation, and that words permit many meanings ("polysemy"), as their meaning is inseparable from the concrete situation in which they are used. At the same time, not only are the words of the speaker present in speech but also multiple voices ("polyphony") - derived from the social horizon of the subject's past and present experiences - which engage in dialogue with and create new meaning for speech.

\section{In summary:}

Bahktin expands the notion of dialog to encompass not only the actual verbal interaction but every type and situation involving "voices" that are in contact. In fact, "words are, initially, the words of others, and, above all, maternal words." Gradually, these "alien words" change through dialog in order to become "one's own alien words," which enter into the dialog along with other words, other voices, and so on. The dynamic movement of dialogue results in a process of "the monologizing of consciousness," which, upon appropriating the words of others, causes one to forget the origin of one's own words (not the individual sense but socio-ideological). This dialogism is thus deeply polysemic and always polyphonic (Smolka, Góes\&Pino, 1995, p.181).

Bakhtin's dialogic perspective opens up important pathways for the understanding of the social formation of the subject. The subject cannot be considered simply an abstract biological organism because he/she is the product of a second social birth. Man is born in a class, in a time period, and is more than just a body, more than just a living organism; man is an ideological, symbolic being. 
Along the same lines, Marinho (1935, p.13) states that "still in its original form, the social environment persists in the individual, integrated with the personality by the influence of language in the formation of the self." The participation of the other in the formation of the subject, therefore, is considered fundamental, primordial, and constitutive of thought and its different manifestations.

Microgenetic-evidentiary analysis of oral-pictorial activity

\section{Background}

In day care centers, schools, shelters, and homes, thousands of observations of small children were recorded and analyzed by the Center for Child Studies (1938) at the Educational Institute of Rio de Janeiro and by the Heloisa Marinho Research Institute (1984), both of which were founded by Heloisa Marinho. Through the observation of these children (aged nine months to seven years old), it was possible to verify the constitutive role of language and the significant mediation of adults and peers. In one of these studies, Marinho and Werner (1982) analyzed a sample made up of 3,000 children between the ages of four and seven from the city of Rio de Janeiro. The children's parents belonged to various professions and hailed from different socioeconomic classes. Data from the graphic activity and oral language of children were analyzed and classified in order to test the importance of the relationship between the oral and graphic modes of communication in the formation of cognition (reading and writing skills), attention, and of other higher psychological functions.

\section{Measures}

An observation script was developed from the results of the studies (Annex 1; Werner, 2012), and has been used in the analysis of the oral-graphic relationship to identify the constitution of thought and other higher mental functions, based on the occurrence of common actions (ocao).

\section{Methods}

The methodology of microgenetic analysis (evidential) involves a number of different uses and forms in its implementation, but is primarily focused on intersubjective relations and requires a consideration of the role of the other in the behavioral regulation of the subject [...] (Werner, 1999, p.167).

According to Werner (2001, p.17), in microgenetic-evidentiary analysis:

(i) the axis of the evaluation of the individual is shifted to the evaluation of [occurring] interactive processes, focusing, for example, on the teacher-student relationship and the interactions among students (Vygostky);

(ii) dialog is emphasized, as Bakhtin proposes; and

(iii) clues, hints, and small signs are valued, as a way to reveal and discover reality. (Evidential paradigm, Ginzburg).

\section{Results}

Following the previously discussed methodology, the graphic activity and the relationship between the oral and graphic modes of communication of a two-year-old boy from a university nursery (Table 1) were observed and analyzed. Results concretely illustrated the significant role of the "participation of the other" in the transformation of the meaning of action and thought in the child.

\section{Table 1}

Sample of the relationship between the oral and graphic modes of communication in a two-year-old boy from the university nursery

\section{Free drawing}

[Transcription of the DIALOG that accompanies the free drawing]

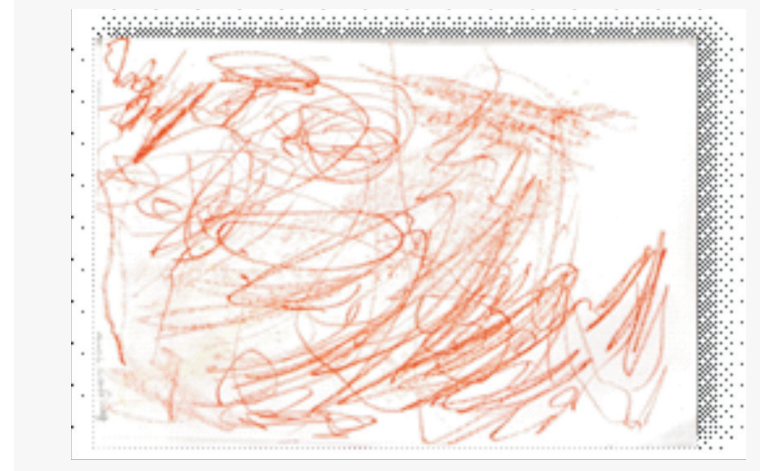

Situation: The children at a nursery are performing the free drawing activity with crayons as the teacher of the class proposed (Teacher). The observer $(\mathrm{O})$ is seated at the table at which there are four children, namely: João, Antônio, Bruno, and Ana (all two years old). [Note: the observer does not have much experience with young children].

1) O:-Look here, look, the crayon, here! [directed at João].

2) Teacher:-Ana, sit up straight!

*3) O:- What are you doing, João? [João was making the first solid lines on the paper, apparently random scribbles].

4) João:- It's drawing! [emphatic]

[After a few seconds, João responds more specifically to the observer]

5) João:-A snake!

6) O:- What? [the observer had not understood what João said]

7) João:-A snake.

8) O:- a snake?

9) João:- Yes! [confirming]

10) O:-Are you making a snake too? [directed at Ana]

11) Ana:- Yes! [confirming]

12) O:- Why are you crossing out the snake, look João? [the observer did not understand that the child was scribbling on the paper and did not have the primary intention to represent a snake, and therefore continued to scribble throughout the entire activity].

Round 13) João:- I'm crossing out a snake! 
[some time later, when the children turned in the drawings to the teacher, the teacher asked the following of João:]

*Round 14) Teacher:- What drawing is that?

Round 15) João:- It's a big whale! [emphatic]

* Note: in general, directly asking the child what she drew should be avoided, as it could indicate that he/she did not know how to draw. In this case, however, due to the fact that the boy's initial goal was not representative, he did not inhibit himself after the adult's intervention, and, on the contrary,

he widened his perception about his own graphic production.

\section{Illustrative Analysis}

In the above example, João (in lines three and four) initially refers to the act of drawing without recognizing or giving significance to any representation. The observer's question, however, makes the boy, after only a few seconds, transform the meaning of the scribble. His action on the paper, initially without a goal to produce any type of graphical representation, is transformed into a snake. The question of the observer when suggesting to João that his scribbles could/should represent something immediately provides new meaning to the action of scribbling, and transforms, by the use of language, the type of relationship between the oral and graphic modes of communication (language-thought-action) presented by the boy. That is, it widens his cognition and enables the incorporation/appropriation of a new (graphic) way of expressing his thought, which will even constitute a base for future reading and writing skills.

In this example, the ready incorporation of new forms of thought, through language and the meaning-making expectations of the adult, demonstrate how the subject appropriates the other through the course of shared actions. Therefore, it is possible to illustrate how dialogue and semiotic mediation play leading roles in the microgenesis of higher mental functions.

\section{Conclusion}

This study found that one of the consequences of semiotic mediation is the establishment of the relationship between thought, language, and action in the graphic activity of the child.

The analysis of the relationship between the oral and graphic modes of communication enabled the individual's process of social microgenesis to be illustrated, or in other words, the role of language mediation in the constitution of the higher mental functions, particularly in the formation of typical human thought.

The observation script that was used (Annex 1) has had promising applications both in the areas of early childhood education and children's mental health.

\section{Final Considerations}

Starting from the general thesis, according to which "the subject is constituted in social relations through language," the issues herein highlighted introduce infinite possibilities for productive interactions, in the sense of expanding Marinho's contributions with other authors within the cultural-historical perspective.
For example, in the field of educational activities for children, the methodological importance of (mediated) construction of the relationship between the oral and graphic modes of communication, regarded as a "prehistory," stands out, not only from learning how to read and write but also from all of the higher mental functions (see item $\mathrm{V}$ in the observation script on Figure 1). The expression of the child, as observed in drawing and oral language, brings forth a wealth of ideas superior to any formal early initiation to reading and writing (like booklets and psychomotor exercises), because childhood education organizes its curriculum so that its principal objective is to widen, through diverse experiences, the language and thought of the child.

\section{References}

Bakhtin,M.(1988). Marxismo e filosofia da linguagem [Marxism and philosophy of language](4th ed.).São Paulo, Brazil: Hucitec.

Marinho,H. (1935). Da linguagem na formação do Eu [Of language and the formation of the self]. Communication presented at the First Inter-American Conference for Mental Higiene, Rio de Janeiro, Brazil.

Marinho,H. (1955). A linguagem na Idade Pré-escolar [Language in the pre-school age]. Rio de Janeiro, Brazil: Ministry of Education and Culture, National Institute of Pedagogical Studies.

Marinho, H.,Werner J.R., J. (1982). Aptidão para aprendizagem da leitura e da escrita [Aptitude for the learning of reading and writing].Rio de Janeiro, Brazil: Bennett Institute for the Development of the Child.

Morato,M.E.(1996). Linguagem e cognição: as reflexões de L.S.Vygotsky sobre a ação reguladora da linguagem. [Language and cognition: The reflections of L.S. Vygotsky on the regulatory action of language].São Paulo, Brazil: Plexus.

Rey,F.G. (1987). La categoria personalidad en la psicologia marxista.[The category of personality in Marxist psychology]. In: Algunas cuestiones teóricas y metológicas sobre el estudio de la personalidad. [Some theoretical and methodological questions on the study of personality] (pp.1-21). Havana, Cuba: Puebloy Educación.

Smolka,A.L.,Góes,M.C.R.,Pino,A.(1995). The Constitution of the subject: a persistent question. In Wertsch, J.V., Delrio, P., Alvarez,A. (Ed.), Sociocultural studies of mind (pp.165-184). New York: Cambridge University Press.

Vygotsky, L.S. (1987). Pensamento e linguagem [Thought and language].São Paulo, Brazil: Martins Fontes.

Vygotsky,L.S. (1988). A formação social da mente [The social formation of the mind].São Paulo, Brazil: MartinsFontes.

Werner JR., J. (1997). Transtornos Hipercinéticos: contribuições do trabalho de Vygotsky para reavaliar o diagnóstico [Hyperkinetic disorders: contributions from the work of Vygotsky to reevaluate diagnotics].(Doctoral dissertation).224 f. State University of Campinas, Campinas, São Paulo, Brazil.

Werner JR., J. (1999). Análise microgenética: Contribuição dos trabalhos de Vigotski para o diagnóstico em psiquiatria infantil / Mikrogenetishe Analyse: Vigotski Beitragzur Diagnose finddung auf dem Gebeit der Kinderpsychiatrie [Microgenetic analysis: Contributions of Vygostsky's work to diagnosis in the field of child psychiatry]. Int. J. Prenatal and Perinatal Psychology and Medicine, 11(2), 157-171. 
WERNER JR., J. Saúde \& Educação: desenvolvimento e aprendizagem do aluno. Rio de Janeiro: Gryphus, 2001.

WERNER JR., J. O papel da linguagem na microgênese das funções psíquicas e sua aplicação no desenvolvimento e aprendizagem da criança. In: COMISSÃO DE VALORIZAÇÃO DA PRIMEIRA INFÂNCIA E CULTURA DA PAZ (Org.). Primeira infância: ideias e intervenções oportunas. Brasília: Senado Federal, 2012. p. 167-261.

WERTSCH, J. V. Vygotsky y la formación social de la mente. Barcelona: Paidós, 1988.

Received: August 29th 2013

Accepted: October 29th 2014

\section{Anexx 1}

Observation script for psychological development

The relationship between the oral and graphic modes of communication in the constitution of thought/higher mental functions (Werner, 2012)

\begin{tabular}{|l|}
\hline I. Correlation between the child's graphic activity and speech \\
\hline a- Does not spontaneously comment on the drawing. \\
\hline b- Refuses to comment on the drawing. \\
\hline c- Responds to questions about the drawing. \\
\hline d- Absence of a relationship between oral commentary and graphic activity. \\
\hline e- Coherence between oral commentary and graphic activity. \\
\hline II- Structure of the relations hip between the oral and graphic \\
modes of communication \\
\hline a. Fantastical narrative. \\
\hline b. Names the drawing. \\
\hline c. Enumerates the elements of the drawing. \\
\hline d. Specifies the drawing. \\
\hline e. Sentence with action verb related to graphic activity. \\
\hline f. Realistic narrative, connected sentences. \\
\hline III- Language that accompanies the action of drawing \\
\hline a. Starting the action. \\
\hline b. Continuing. \\
\hline c. Finishing the action. \\
\hline d. Describing the action. \\
\hline e. Announcing the action. \\
\hline f. Transforming the action. \\
\hline g. Giving meaning to the action. \\
\hline h. Changing the meaning of the action. \\
\hline IV- Language functions \\
\hline a. Communication/Social Language. \\
\hline b. Speaking to oneself (soliloquy)/Egocentric Language. \\
\hline c. Regulating the behavior of the other. \\
\hline d. Regulating one's own behavior. \\
\hline e. Determining/influencing/ modifying perception. \\
\hline f. Enabling past things to be evoked (memory). \\
\hline g. Allowing future actions to be planned. \\
\hline h. Organizing actions. \\
\hline i. Expressing thought. \\
\hline j. Directing the focus of attention. \\
\hline k. Constituting thought (verbal thought). \\
\hline l. Appropriating alien words (incorporating the words of the other). \\
\hline V- Higher mental functions constituted by language \\
\hline a. Memory. Mediated. \\
\hline b. Voluntary attention \\
\hline c. Perception \\
\hline d. Cognition \\
\hline e. Imagination \\
\hline f. Practical thought \\
\hline g. Verbal thought \\
\hline h. Consciousness and will \\
\hline i. Executive functions (planning and execution) \\
\hline
\end{tabular}

